\title{
Analysis of antimicrobial susceptibility and virulence factors in Helicobacter pylori clinical isolates
}

Anita Paula Ortiz Godoy, Marcelo Lima Ribeiro, Yune Helena

Borges Benvengo, Lea Vitiello, Maira de Carvalho Bueno Miranda, Sergio Mendonça and José Pedrazzoli Jr*

Address: Clinical Pharmacology and Gastroenterology Unit, São Francisco University Medical School, Bragança Paulista, SP, Brazil

Email: Anita Paula Ortiz Godoy - anita@ helicobacter.com.br; Marcelo Lima Ribeiro - marceloribeiro@saofrancisco.edu.br; Yune Helena Borges Benvengo - yune@helicobacter.com.br; Lea Vitiello - lea@helicobacter.com.br; Maira de

Carvalho Bueno Miranda - maira@helicobacter.com.br; Sergio Mendonça - sergiomendonca@saofrancisco.edu.br;

José Pedrazzoli* - pedrazzoli@saofrancisco.edu.br

* Corresponding author

Published: II August 2003

BMC Gastroenterology 2003, 3:20
Received: 17 June 2003

Accepted: II August 2003

This article is available from: http://www.biomedcentral.com/l47I-230X/3/20

(C) 2003 Godoy et al; licensee BioMed Central Ltd. This is an Open Access article: verbatim copying and redistribution of this article are permitted in all media for any purpose, provided this notice is preserved along with the article's original URL.

\begin{abstract}
Background: In this study, we evaluated the prevalence of primary resistance of Brazilian $\mathrm{H}$. pylori isolates to metronidazole, clarithromycin, amoxicillin, tetracycline, and furazolidone. In addition, the vacA, iceA, cagA and cagE genotypes of strains isolated from Brazilian patients were determined and associated with clinical data in an effort to correlate these four virulence markers and antibiotic resistance.
\end{abstract}

Methods: $\mathrm{H}$. pylori was cultured in $155 \mathrm{H}$. pylori-positive patients and MICs for metronidazole, clarithromycin, amoxicillin, tetracycline, and furazolidone were determined by the agar dilution method. Genomic DNA was extracted, and allelic variants of vacA, iceA, cagA and cagE were identified by the polymerase chain reaction.

Results: There was a strong association between the vacA sl/cagA -positive genotype and peptic ulcer disease $(O R=5.42,95 \% \mathrm{Cl} 2.6-1 \mathrm{I} .3, \mathrm{p}=0.0006)$. Additionally, infection by more virulent strains may protect against GERD, since logistic regression showed a negative association between the more virulent strain, vacA sl/cagA-positive genotype and GERD (OR $=0.26,95 \% \mathrm{Cl} 0.08-0.8$, $P=0.03)$. Resistance to metronidazole was detected in 75 patients $(55 \%)$, to amoxicillin in 54 individuals (38\%), to clarithromycin in 23 patients $(16 \%)$, to tetracycline in 13 patients $(9 \%)$, and to furazolidone in 19 individuals (13\%). No significant correlation between pathogenicity and resistance or susceptibility was detected when MIC values for each antibiotic were compared with different vacA, iceA, cagA and cagE genotypes.

Conclusion: The analysis of virulence genes revealed a specific association between $\mathrm{H}$. pylori strains and clinical outcome, furthermore, no significant association was detected among pathogenicity and resistance or susceptibility. 


\section{Background}

Helicobacter pylori is a gastric pathogen that chronically infects more than half of the world's population, with a prevalence ranging from $25 \%$ in developed countries to more than $90 \%$ in developing areas [1]. Infection with $H$. pylori is associated with chronic superficial gastritis, peptic ulceration and gastric cancer. The reason for such a clinically diverse outcome of infection remains uncertain, but may include host and environmental factors as well as differences in the prevalence or expression of bacterial virulence factors [1].

The cagA gene (cytotoxin-associated gene) is considered to be a marker for the presence of a pathogenicity island ( $\mathrm{cag}$ PAI), and individuals infected with cagA-positive H. pylori strains have a higher risk of developing peptic ulcers and gastric cancer [2-4]. Several studies have reported that some strains may contain a partially-deleted cag PAI [5]. Thus, the presence of the cagA gene does not guarantee that critical genes within the cag PAI are intact [6], however the cagE gene appears to be a better marker of intact cag PAI than the cagA gene [6,7].

The vacA gene encodes a vacuolating toxin excreted by $H$. pylori, which has been associated with epithelial cell damage [8]. This gene is present in all strains and comprises two variable parts $[2,9]$, the s-region (signal) and the mregion (middle) [3]. The production of vacuolating cytotoxin is related to the mosaic combination of $\mathrm{s}$ and $\mathrm{m}$ allelic types. The mosaic combination of the vacA gene has been associated with specific genotypes and different clinical outcomes $[3,4,10]$.

The gene designated, iceA (induced by contact with epithelium), has two main allelic variants, iceA 1 and iceA 2. Although iceA1 has been associated with peptic ulcer disease [3], other studies have failed to confirm this correlation, and some groups have suggested an inverse relationship $[5,11]$.

H. pylori infection can be cured by antibiotics, however the ideal anti-H. pylori treatment has yet to be found $[12,13]$. Many factors have been implicated in treatment failure, including ineffective penetration of antibiotics into the gastric mucosa, antibiotic inactivation by low gastric $\mathrm{pH}$, lack of compliance, and emergence of acquired antibiotic resistance by $H$. pylori $[3,14]$. Despite the success of the current anti-Helicobacter therapies, it is suggested that eradication rates among patients with gastritis are lower than among patients with peptic ulcer disease, with the causes of this phenomenon still being the subject of speculation [15].

In this study, we aimed to correlate primary resistance of Brazilian H. pylori isolates to metronidazole, clarithromy- cin, amoxicillin, tetracycline, and furazolidone with vacA, ice A, cagA and cagE status and clinical outcome.

\section{Methods \\ Patients}

Helicobacter pylori isolates were obtained from 155 patients ( 86 males and 69 females; age $43.6 \pm 14.9$ years) living in southeastern Brazil. Eighty patients with peptic ulcer disease (PUD), 54 with non-ulcer dyspepsia (NUD) and 21 with gastroesophageal reflux disease (GERD) were included. The study was approved by the Ethics Committee of the São Francisco University and performed in accordance with the Declaration of Helsinki. Each patient signed a written informed consent prior to entering the study.

\section{H. pylori culture and MIC determination}

$H$. pylori isolates were obtained by inoculating the specimens into selective media followed by incubation for 3-5 days at $37^{\circ} \mathrm{C}$ under microaerophilic conditions, as previously described [16]. The colonies were identified by Gram staining and by oxidase, catalase and urease production. $H$. pylori strains were stored at $-70^{\circ} \mathrm{C}$ in $\mathrm{BHI}$ broth containing glycerol $30 \%$. The MIC for amoxicillin, furazolidone, metronidazole, tetracycline (Sigma Chemical Co., St Louis, MO) and clarithromycin (Abbot Laboratories, North Chicago, Ill) were determined by the agar dilution method, using twofold increments (0.125 to 256 $\mu \mathrm{g} \mathrm{ml}^{-1}$ ) on Mueller-Hinton agar (Merck, Darmstadt, Germany) supplemented with $10 \%$ sheep blood, and incubated at $37^{\circ} \mathrm{C}$ under microaerophilic conditions for $72 \mathrm{~h}$. All tests were performed in duplicate. Isolates were considered to be resistant when the MIC was greater than $8 \mu \mathrm{g}$ $\mathrm{ml}^{-1}$ for amoxicillin or metronidazole, and greater than 2 $\mu \mathrm{g} \mathrm{ml}^{-1}$ for clarithromycin, furazolidone or tetracycline [16].

\section{Molecular Biology Methods}

Genomic DNA was extracted with DNAzol ${ }^{\mathrm{TM}}$ reagent (Gibco BRL, Cincinnati, OH, USA), and the integrity of the DNA was assessed by electrophoresis in $0.8 \%$ agarose gels stained with ethidium bromide.

Polymerase chain reactions (PCR) were performed in a total volume of $50 \mu \mathrm{l}$ containing $50 \mathrm{pmol}$ of primer, 100 ng of genomic DNA, $1.0 \mathrm{mmol} \mathrm{L}^{-1}$ of each of four dNTPs (Invitrogen $^{\mathrm{TM}}$ Life Technologies, Alemeda, CA, USA) and

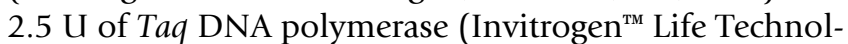
ogies). The reaction mixtures were cycled in an automated GeneAmp ${ }^{\circledast}$ PCR System 9700 thermal cycler (PE Applied Biosystems, Foster City, CA, USA) under the following conditions: initial denaturation at $95^{\circ} \mathrm{C}$ for $5 \mathrm{~min}$ followed by 35 cycles of denaturation at $95^{\circ} \mathrm{C}$ for $1 \mathrm{~min}$, annealing ranging from $45^{\circ} \mathrm{C}$ to $60^{\circ} \mathrm{C}$ for $1 \mathrm{~min}$ and 
Table I: The vacA, iceA, cagA and cagE status of $H$. pylori strains and clinical outcome

\begin{tabular}{|c|c|c|c|c|}
\hline \multirow[b]{2}{*}{ Genotype } & \multicolumn{4}{|c|}{ Clinical Outcome } \\
\hline & PUD n (\%) & NUD n (\%) & GERD n (\%) & Total n (\%) \\
\hline \multicolumn{5}{|l|}{$\operatorname{vacA}$} \\
\hline sl & $57(78)^{*}$ & $25(54)$ & $4(2 I)$ & $86(62)$ \\
\hline s2 & $16(22)$ & $21(46)$ & $15(79)^{* * *}$ & $52(38)$ \\
\hline $\mathrm{ml}$ & $27(37)$ & II (24) & $3(16)$ & $41(30)$ \\
\hline $\mathrm{m} 2$ & $46(63)$ & $35(76)$ & $16(84)$ & $97(70)$ \\
\hline $\mathrm{s} \mid \mathrm{ml}$ & $27(37)$ & II (24) & $3(16)$ & $41(30)$ \\
\hline $\mathrm{s} \operatorname{lm} 2$ & $30(4 I)^{*}$ & $14(30)$ & I (5) & $45(32)$ \\
\hline$s 2 m 2$ & $16(22)$ & $21(46)$ & $15(79) * *$ & $52(38)$ \\
\hline \multicolumn{5}{|l|}{ ice $A$} \\
\hline iceAl & $12(16)$ & $6(13)$ & $3(16)$ & $21(15)$ \\
\hline iceA2 & $55(75)$ & $32(70)$ & $15(79)$ & $102(74)$ \\
\hline iceA - & $6(9)$ & $8(17)$ & I (5) & $15(11)$ \\
\hline \multicolumn{5}{|l|}{$\operatorname{cag} A$} \\
\hline $\operatorname{cag} A+$ & $55(75)^{*}$ & $25(54)$ & $9(47)$ & $89(65)$ \\
\hline cagA - & $18(25)$ & $21(46)$ & $10(53)$ & $49(35)$ \\
\hline \multicolumn{5}{|l|}{ cage } \\
\hline $\operatorname{cag} E+$ & $60(82)$ & $39(85)$ & $17(90)$ & $116(84)$ \\
\hline cagE - & $13(13)$ & $6(15)$ & $2(10)$ & $22(16)$ \\
\hline
\end{tabular}

$*$ vacA sI $\left(\chi^{2}=14.3 ; p=0.0002\right) \operatorname{sIm} 2\left(\chi^{2}=15.67 ; p=0.0004\right) \operatorname{cag} A\left(\chi^{2}=7.954 ; p=0.0048\right) . * * \operatorname{s} 2 \mathrm{~m} 2\left(\chi^{2}=16.89 ; p=0.0002\right)$

$72^{\circ} \mathrm{C}$ for $1 \mathrm{~min}$. The final cycle included a 7 min extension step to ensure full extension of the PCR products.

The presence of $H$. pylori was confirmed by PCR of the $16 \mathrm{~S}$ rRNA [17] and glmM [18] genes. The cagA gene was analyzed using the primers D008 and R008 [19]. The cagE gene was analyzed using the primers described by Fallone et al. [10]. For analysis of the vacA m region, primers VA3$\mathrm{F}$ and VA3-R were used, whereas primers VA4-F and VA4$\mathrm{R}$ were used to amplify the $\mathrm{m} 1$ and $\mathrm{m} 2$ subtypes, respectively [5]. The vacA s region was analyzed using the primers, VA1-F and VA1-R [5]. For iceA genotype analysis, primers iceA1-F, iceA1-R, iceA2-F and iceA2-R were used. The primers, iceA2-F and iceA2-R, yielded a fragment of 124,229 or 334 bp depending on the existence of repeated sequences of 105 nucleotides [3].

\section{Statistical analysis}

The association between $H$. pylori genotypes and clinical disease, as well as among the virulence markers and antibiotic resistance was evaluated using either the $\chi^{2}$ test with Yates continuity correction or Fisher's exact test. Only cases containing single genotypes were included. Logistic regression analysis was used to evaulate the relationship between virulence markers and antibiotic resistance of $\mathrm{H}$. pylori and clinical outcome. A logistic regression model was constructed using variables such as cagA, vacA and iceA status, and antibiotic resistance. The association of each variable with PUD or NUD or GERD (dependent var- iables) was tested by univariated analysis. All variables with $\mathrm{p}$ values of 0.25 or less were included in the full model of logistic regression and variables with $\mathrm{p}$ values $<0.05$ were remained in the model. The odds ratio (OR) and the $95 \%$ confidence interval $(95 \% \mathrm{CI})$ were used as estimates of the risk.

\section{Results and Discussion Virulence factors}

The presence of the genes vacA, cagA, cagE and iceA were investigated in all 155 clinical isolates positive for $16 \mathrm{~S}$ rRNA and for glmM. Based on the vacA and iceA genotypes, 138 (89\%) specimens were colonized by a single $\mathrm{H}$. pylori strain. More than one strain was detected in 17 isolates and none of these patients were included in either the analysis of the relationship between clinical disease with the virulence factors or with antibiotic resistance. Since the prevalence of $\mathrm{H}$. pylori infection, in our geographic region, reaches $80 \%$, such prevalence of multiple infection would be expected [20].

The vacA $\mathrm{s}$ and $\mathrm{m}$ genotype could be identified in all cases studied. Most of the isolates had the s1 signal sequence allele $(62 \%)$. The prevalence of vacA s1 was significantly higher in $H$. pylori isolates from PUD patients $\left(\chi^{2}=14.3 \mathrm{p}\right.$ $=0.0002)$. The vacA $\mathrm{m} 1$ allele was found in $41(30 \%)$ and the $\mathrm{m} 2$ allele in $97(70 \%)$ of the samples. There was no relationship between vacA $\mathrm{m}$ and clinical outcome. Considering the $H$. pylori isolates with only one single geno- 
type (138), three mosaic combinations were found: $\mathrm{s} 1 \mathrm{~m} 1$ (30\%), s1m2 (32\%), and s $2 \mathrm{~m} 2$ (38\%). Statistical analysis showed a significant association between PUD and $\mathrm{s} 1 \mathrm{~m} 2$ $\left(\chi^{2}=15.67 ; p=0.0004\right)$, and between GERD and the s2m2 genotype $\left(\chi^{2}=16.89 ; p=0.0002\right.$, Table 1$)$.

The iceA1 genotype was detected in $21(15 \%)$ of the 138 isolates analyzed, while iceA2 was found in 102 cases (74\%). Fifteen isolates (11\%) did not yield any PCR product for iceA (Table 1). There was no relationship between the size of the iceA2 amplicon and the patient's disease. In contrast to results obtained by others, ice 2 was the most frequent genotype detected in our population $[21,22]$. In this study, the iceA type was not associated with the clinical outcome, as previously described [11,21].

With regard to the cag PAI, the cagA gene was present in 89 $(65 \%)$ of the $138 \mathrm{H}$. pylori isolates, whereas the cagE gene was present in $116(84 \%)$ isolates (Table 1). Both genes were absent in $11 \%(15 / 138)$ of the isolates and, in these cases, the cag PAI could also be absent. There was an association between PUD and the presence of the cagA $\left(\chi^{2}=\right.$ $7.954 ; p=0.0048)$. Our data are supported by previous reports and suggest that individuals colonized with cagApositive $H$. pylori strains are at increased risk of developing peptic ulceration $[3,4]$. Conversely, no association was detected between cagE genotypes and clinical outcome.

The combination of the cagA and vacA status was also investigated. An association was observed between the genotype, cagA-positive vacA s 1 and PUD $\left(\chi^{2}=11.871 ; p\right.$ $=0.0006)$ and between GERD and the cagA-negative vacA s2 genotype $(p<0.0001)$. Although our data showed a trend towards an association between the cagA-positive, vacA s $1 \mathrm{~m} 2$ genotype and PUD $\left(\chi^{2}=13.849 ; p=0.001\right)$, logistic regression analysis suggested that this could be explained by a higher prevalence of the cagA and vacA s1 alleles $(\mathrm{OR}=5.42,95 \%$ CI 2.6-11.3, $\mathrm{p}=0.0006)$ This finding agrees with those of others reports and suggests a possible role for these factors in the pathogenesis of $H$. pylori-related peptic ulceration $[3,4]$. Gastroesophageal reflux disease (GERD) results from exposure of the esophageal mucosa to acid [23]. There is no apparent causal relationship between $H$. pylori colonization and the presence of GERD or its complications, although GERD patients are infected with less virulent $H$. pylori strains [24]. Infection by H. pylori may protect against GERD, thus these patients may have a lower frequency of vacA s1 genotype and a higher frequency of the vacA s2 and $\mathrm{m} 2$ genotypes $[4,10,25]$. Our data support this hypothesis and logistic regression showed a negative association between the more virulent strain, cagA-positive vacA s1 genotype, and GERD (OR = 0.26, 95\% CI 0.08-0.8, p = $0.03)$. Although the protective effect of infection with cagA-positive $H$. pylori strains against GERD could be explained by the lower gastric output due to the more intense gastric lesions induced by these strains [26]. Further studies are required to determine the putative protective role of the more virulent strains.

\section{Antimicrobial Susceptibility}

H. pylori resistance to antimicrobial is of particular concern because it is a major determinant of eradication regimen failure. We tested the primary resistance to amoxicillin, clarithromycin, furazolidone, metronidazole and tetracycline in $138 \mathrm{H}$. pylori isolates.

Until recently, resistance to amoxicillin was considered to be absent or very rare, however, amoxicillin-resistant $H$. pylori strains have now been identified in USA, Italy and Brazil $[16,27,28]$. In this study, the amoxicillin resistance was found in $39 \%$ of isolates (54/138). The reason for these high rates of amoxicillin resistance remains unclear, however, since no pharmaco-epidemiological data regarding amoxicillin use in Brazil exists, it may be speculated that this drug is used in a disproportionate manner.

The increased consumption of macrolides is expected to influence the prevalence of $H$. pylori resistance to clarithromycin. Resistance to clarithromycin was detected in $16 \%$ of strains $(23 / 138)$. Our results agree with previous reports from Brazil, being lower those from Peru [29] and higher than rates in Europe [30]. Resistance to clarithromycin has a serious clinical implication, since it impairs the efficacy effect of anti-H. pylori treatment [31].

The occurrence of metronidazole-resistant strains may be the consequence of increased consumption of this antibiotic in the community. In this study, the resistance to metronidazol was observed in 54\% (75/138) of strains. Metronidazole has been widely prescribed for other infections such as parasitic or genital infections, and the use or abuse of this inexpensive drug may contribute to the increase in metronidazole resistance, with rates ranging from $5 \%$ to $90 \%$ [32].

Tetracyclines are a family of broad-spectrum antibiotics that have been widely used for the treatment of bacterial infections since the 1950s. Until the end of the last century, only a few cases of spontaneous tetracycline resistance in $H$. pylori had been reported [33]. During the last 3 years, however, an increase in the incidence of tetracycline resistance in $H$. pylori has been reported. In this study, we found $9 \%(13 / 138)$ of tetracycline resistance in strains. Similar data were published in previous reports [16,34].

Furazolidone has been used as an alternative to overcome metronidazole resistance. In our study, resistance to furazolidone was 13\% (19/138), higher than rates detected by others [22]. The reason for the high rate of furazolidone 
resistance and factors leading to it are still unknown and deserve further investigation.

Thirty one strains were resistant to two agents, 19 isolates to three drugs, and 3 strains to four antimicrobials. $H$. pylori resistance to these antimicrobials may be partially explained by the high prevalence of this bacteria in our population. Eradication failure has been associated with several reasons, the most important being primary $H$. pylori resistance.

Additionally, the primary $H$. pylori resistance was related to the clinical outcome, as well as to virulence factors. We were unable to detect an association between outcome and bacterial resistance, as previously reported [35,36]. With regard to virulence factors, no association was found when the MIC values for metronidazole, amoxicillin, clarithromycin, tetracycline, and furazolidone were compared with the different vacA, ice $\mathrm{A}, \operatorname{cag} \mathrm{A}$ and $\operatorname{cag} \mathrm{E}$ genotypes, as described by several authors [35,37]. Thus, it seems that different virulence markers and antibiotic resistance in $H$. pylori strains are not interrelated.

\section{Conclusions}

In conclusion, the analysis of virulence genes revealed a specific association between $H$. pylori strains and clinical outcome. Our data suggest an association between cagApositive, vacA s1 genotype, and PUD and also support the hypothesis that virulent strains may protect against GERD development. Furthermore, no significant correlation was detected among pathogenicity and resistance or susceptibility.

\section{List of abbreviations}

PUD - peptic ulcer disease; NUD - non-ulcer dyspepsia; GERD - gastroesophageal reflux disease; PCR - Polymerase chain reaction.

\section{Competing interests}

None declared.

\section{Author's contributions}

APOG, MLR and MCBM carried out the molecular genetic studies; APOG, YHBB, LV and SM participated in the antimicrobial susceptibility analysis; APOG and MLR drafted the manuscript; MLR and APOG performed the statistical analysis; MLR, SM and JPJ participated in the design of the study and coordination; All authors read and approved the final manuscript.

\section{Acknowledgements}

This work was supported by a grant from Fundação de Amparo à Pesquisa do Estado de São Paulo - FAPESP (01/12369-I).

\section{References}

I. Blaser MJ: Ecology of Helicobacter pylori in the human stomach. J Clin Invest 1997, 100:759-762.

2. Cover TL, Dooley CP and Blaser MJ: Characterization of and human serologic response to proteins in Helicobacter pylori broth culture supernatants with vacuolizing cytotoxin activity. Infect Immun 1990, 58:603-6I0.

3. van Doorn LJ, Figueiredo C, Sanna R, Plaisier A, Schneeberger P, de Boer $W$ and $Q$ uint $W$ : Clinical relevance of the cagA, vacA, and iceA status of Helicobacter pylori. Gastroenterology 1998, I 1 5:58-66.

4. Arents NL, van Zwet AA, Thijs JC, Kooistra-Smid AM, van Slochteren KR, Degener JE, Kleibeuker JH and van Doorn LJ: The importance of vacA, cagA, and iceA genotypes of Helicobacter pylori infection in peptic ulcer disease and gastroesophageal reflux disease. Am J Gastroenterol 200 I, 96:2603-2608.

5. Mukhopadhyay AK, Kersulyte D, Jeong JY, Datta S, Ito Y, Chowdhury A, Chowdhury S, Santra A, Bhattacharya SK, Azuma T, Nair GB and Berg DE: Distinctiveness of genotypes of Helicobacter pylori in Calcutta, India. J Bacteriol 2000, 182:3219-3227.

6. Hsu PI, Hwang IR, Cittelly D, Lai KH, El-Zimaity HM, Gutierrez O, Kim JG, Osato MS, Graham DY and Yamaoka Y: Clinical presentation in relation to diversity within the Helicobacter pylori cag pathogenicity island. Am J Gastroenterol 2002, 97:223I-2238.

7. Ikenoue T, Maeda S, Ogura K, Akanuma M, Mitsuno Y, Imai Y, Yoshida $\mathrm{H}$, Shiratori $\mathrm{Y}$ and Omata M: Determination of Helicobacter pylori virulence by simple gene analysis of the cag pathogenicity island. Clin Diagn Lab Immunol 200I, 8: I8I-I86.

8. Telford JL, Ghiara P, Dell'Orco M, Comanducci M, Burroni D, Bugnoli M, Tecce MF, Censini S, Covacci A and Xiang Z: Gene structure of the Helicobacter pylori cytotoxin and evidence of its key role in gastric disease. J Exp Med 1994, 179:1653-1658.

9. Atherton JC, Cao P, Peek RM, Tummuru MK, Blaser MJ and Cover TL: Mosaicism in vacuolating cytotoxin alleles of Helicobacter pylori. Association of specific vacA types with cytotoxin production and peptic ulceration. J Biol Chem 1995, 270:1777I-17777.

10. Fallone CA, Barkun AN, Gottke MU, Best LM, Loo VG, Veldhuyzen van Zanten, Nguyen T, Lowe A, Fainsilber T, Kouri K and Beech R: Association of Helicobacter pylori genotype with gastroesophageal reflux disease and other upper gastrointestinal diseases. Am J Gastroenterol 2000, 95:659-669.

II. Yamaoka Y, Kodama T, Gutierrez O, Kim JG, Kashima K and Graham DY: Relationship between Helicobacter pylori iceA, cagA, and vacA status and clinical outcome: studies in four different countries. J Clin Microbiol 1999, 37:2274-2279.

12. de Boer WA and Tytgat GN: $\mathbf{9 0 \%}$ cure: which anti-Helicobacter therapy can achieve this treatment goal? Am J Gastroenterol 1995, 90:138I-1382.

13. Ecclissato C, Marchioretto MA, Mendonca S, Godoy AP, Gersoni RA, Deguer M, Piovesan H, Ferraz JG and Pedrazzoli J: Increased primary resistance to recommended antibiotics negatively affects Helicobacter pylori eradication. Helicobacter 2002, 7:53-9.

14. Alarcon A, Talavera G, Gonzales J and Rivera J: Esophageal stenosis in children: medical treatment experience. Rev Gastroenterol Peru 1999, 1 9:26I-272.

15. van Doorn LJ, Schneeberger PM, Nouhan N, Plaisier AP, Quint WG and de Boer WA: Importance of Helicobacter pylori cagA and vacA status for the efficacy of antibiotic treatment. Gut 2000 , 46:32I-326.

16. Mendonca S, Ecclissato C, Sartori MS, Godoy AP, Guerzoni RA, Degger $M$ and Pedrazzoli Jj: Prevalence of Helicobacter pylori resistance to metronidazole, clarithromycin, amoxicillin, tetracycline, and furazolidone in Brazil. Helicobacter 2000, 5:79-83.

17. Ho SA, Hoyle JA, Lewis FA, Secker AD, Cross D, Mapstone NP, Dixon MF, Wyatt JI, Tompkins DS and Taylor GR: Direct polymerase chain reaction test for detection of Helicobacter pylori in humans and animals. J Clin Microbiol I99I, 29:2543-2549.

18. Bickley J, Owen RJ, Fraser AG and Pounder RE: Evaluation of the polymerase chain reaction for detecting the urease $C$ gene of Helicobacter pylori in gastric biopsy samples and dental plaque. J Med Microbiol 1993, 39:338-344.

19. Covacci A, Censini S, Bugnoli M, Petracca R, Burroni D, Macchia G, Massone A, Papini E, Xiang Z and Figura N: Molecular characterization of the I28-kDa immunodominant antigen of Helico- 
bacter pylori associated with cytotoxicity and duodenal ulcer. Proc Natl Acad Sci U S A 1993, 90:5791-5795.

20. Carvalho AS, Queiroz DM, Mendes EN, Rocha GA and Penna FJ: Diagnosis and distribution of Helicobacter pylori in the gastric mucosa of symptomatic children. Braz J Med Biol Res I99I, 24:163-166.

21. Ashour AA, Collares GB, Mendes EN, de Gusmao VR, Queiroz DM, Magalhaes PP, de Carvalho AS, de Oliveira CA, Nogueira AM, Rocha GA and Rocha AM: iceA genotypes of Helicobacter pylori strains isolated from Brazilian children and adults. J Clin Microbiol 200 I, 39: $1746-1750$.

22. Kim SY, Woo CW, Lee YM, Son BR, Kim JW, Chae HB, Youn SJ and Park SM: Genotyping cagA, vacA subtype, iceA I, and babA of Helicobacter pylori isolates from Korean patients, and their association with gastroduodenal diseases. J Korean Med Sci 2001, 16:579-584.

23. Castell DO: Physiology and pathophysiology of the lower esophageal sphincter. Ann Otol Rhinol Laryngol 1975, 84:569-575.

24. Werdmuller BF and Loffeld RJ: Helicobacter pylori infection has no role in the pathogenesis of reflux esophagitis. Dig Dis Sci 1997, 42:103-105.

25. Loffeld RJ, Werdmuller BF, Kusters JG, Perez-Perez GI, Blaser MJ and Kuipers E): Colonization with cagA-positive Helicobacter pylori strains inversely associated with reflux esophagitis and Barrett's esophagus. Digestion 2000, 62:95-99.

26. Queiroz DM, Rocha GA, Oliveira CA, Rocha AM, Santos A, Cabral $M M$ and Nogueira AM: Role of corpus gastritis and cagA-positive Helicobacter pylori infection in reflux esophagitis. J Clin Microbiol 2002, 40:2849-2853.

27. Fedorak R, Archambault A, Flamm R, Osato M and Stamler D: Antimicrobial susceptibility of $H$. pylori in Canada to three key antibiotics: metronidazole, clarithromycin, and amoxicillin [Abstract]. Gastroenterology 1997, II 2:AIII5.

28. Dore MP, Pianna A, Carta M, Atzei A, Are BM, Mura I, Massarelli G, Maida A, Sepulveda AR, Graham DY and Realdi G: Amoxycillin resistance is one reason for failure of amoxycillin-omeprazole treatment of Helicobacter pylori infection. Aliment Pharmacol Ther 1998, I 2:635-639.

29. Vasquez A, Valdez Y, Gilman RH, McDonald J], Westblom TU, Berg $D$, Mayta $\mathrm{H}$ and Gutierrez $\mathrm{V}$ : Metronidazole and clarithromycin resistance in Helicobacter pylori determined by measuring MICs of antimicrobial agents in color indicator egg yolk agar in a miniwell format. J Clin Microbiol 1996, 34:1232-1234.

30. Debets-Ossenkopp YJ, Herscheid AJ, Pot RG, Kuipers EJ, Kusters JG and Vandenbroucke-graus CM: Prevalence of Helicobacter pylori resistance to metronidazole, clarithromycin, amoxycillin, tetracycline and trovafloxacin in The Netherlands. J Antimicrob Chemother 1999, 43:5II-5I5.

3I. Graham DY, Genta R, Evans DG, Reddy R, Clarridge JE, Olson CA, Edmons AL and Siepman N: Helicobacter pylori does not migrate from the antrum to the corpus in response to omeprazole. Am J Gastroenterol 1996, 91:2120-2124.

32. Goddart AF and Logan RP: Antimicrobial resistance and Helicobacter pylori. J Antimicrob Chemother 1996, 37:639-43.

33. Kwon DH, Kim JJ, Lee M, Yamaoka Y, Kato M, Osato MS, El-Zaatari FA and Graham DY: Isolation and characterization of tetracycline-resistant clinical isolates of Helicobacter pylori. Antimicrob Agents Chemother 2000, 44:3203-3205.

34. Ani AE, Malu AO, Onah JA, Queiroz DM, Kirschner G and Rocha GA Antimicrobial susceptibility test of Helicobacter pylori isolated from Nigeria. Trans $R$ Soc Trop Med Hyg 1999, 93:659-66I.

35. Loivukene K, Kolk H, Maaroos HI, Kasenomm P, Ustav M and Mikelsaar M: Metronidazole and clarithromycin susceptibility and the subtypes of vac $A$ of Helicobacter pylori isolates in Estonia. Scand J Infect Dis 2000, 32:59-62.

36. Boyanova L, Koumanova R, Gergova G, Popova M, Mitov I, Kovacheva Y, Derejian S, Katsarov N, Nikolov R and Krastev Z: Prevalence of resistant Helicobacter pylori isolates in Bulgarian children. J Med Microbiol 2002, 5 I:786-790.

37. Damaso D, Alarcon T, Prieto $\mathrm{N}$ and Lopez-Brea M: Relationship between antimicrobial susceptibility and virulence factors in Helicobacter pylori clinical isolates. Rev Esp Quimioter 1999, 1 2:340-345.

\section{Pre-publication history}

The pre-publication history for this paper can be accessed here:

http://www.biomedcentral.com/1471-230X/3/20/pre pub
Publish with Bio Med Central and every scientist can read your work free of charge

"BioMed Central will be the most significant development for disseminating the results of biomedical research in our lifetime. "

Sir Paul Nurse, Cancer Research UK

Your research papers will be:

- available free of charge to the entire biomedical community

- peer reviewed and published immediately upon acceptance

- cited in PubMed and archived on PubMed Central

- yours - you keep the copyright

Submit your manuscript here:

http://www.biomedcentral.com/info/publishing_adv.asp
BiolMedcentral 